\title{
Pengaruh Biaya Modal dan Profitabilitas Terhadap Nilai Saham Bank BTPN Syariah Periode 2018-2020
}

\author{
Siska Yuli Anita \\ Universitas Islam Negeri Raden Intan Lampung, Indonesia. \\ siskayulianita@radenintan.ac.id
}

*Corresponding Author

Diajukan : 28 Nopember 2021

Disetujui : 15 Desember 2021

Dipublikasi : : 1 Januari 2022

\begin{abstract}
Operations and investments of Islamic banks certainly require capital as the foundation and start of the bank's business, so estimating the cost of capital required is an important process and good corporate profits will provide a good image for the company. This study aims to determine the effect of capital with the Weighted Average Cost Of Capital (WACC) method on stock values. The effect of profitability with the ratio of Return On Equity (ROE) on stock value. And the effect of the cost of capital and profitability on the value of the stock. This study uses a descriptive quantitative research method. By using secondary data in the form of monthly financial statements of Bank BTPN Syariah for the 2018-2020 period. All of these data are materials for estimating and calculating the cost of capital and profitability of Bank BTPN Syariah. The results showed that partially the cost of capital had a significant positive effect on the stock value, profitability had a significant negative effect on the stock value. Meanwhile, simultaneously the cost of capital and profitability affect the value of the stock.
\end{abstract}

\section{Keywords : Cost Capital, Profitability, Stock Value}

\section{PENDAHULUAN}

Penguasaan pangsa pasar bank syariah di industri perbankan syariah nasional masih kalah jauh dibandingkan dengan bank konvensional, pangsa pasar bank syariah di indonesia pada tahun 2020 baru mencapai $6,18 \% .5$ Ternyata tidak menjadikan perbankan syariah di Indonesia menjadi nomor satu. Hal ini sangat disayangkan karena potensi yang dimiliki Indonesia sebetulnya sangat besar, seharusnya dengan populasi islam terbesar di dunia itu berbanding lurus dengan kejayaan perbankan syariah di Indonesia.

Tabel 1.1

Indikator Utama Perbankan Syariah 2020

\begin{tabular}{|l|l|l|l|l|l|}
\hline $\begin{array}{c}\text { Industri } \\
\text { Perbankan }\end{array}$ & \multicolumn{1}{|c|}{$\begin{array}{c}\text { Jumlah } \\
\text { Institusi }\end{array}$} & $\begin{array}{c}\text { Jumlah } \\
\text { Kantor }\end{array}$ & $\begin{array}{c}\text { Aset } \\
\text { (Triliun Rp) }\end{array}$ & $\begin{array}{c}\text { PYD } \\
\text { (Triliun Rp) }\end{array}$ & $\begin{array}{c}\text { DPK } \\
\text { (Triliun Rp) }\end{array}$ \\
\hline BUS & 14 & 1942 & 356,33 & 232,15 & 293,37 \\
\hline UUS & 20 & 390 & 175,45 & 134,16 & 127,95 \\
\hline BPRS & 162 & 626 & 13,61 & 10,50 & 8,89 \\
\hline \multicolumn{1}{|c|}{ Total } & $\mathbf{1 9 6}$ & $\mathbf{2 9 5 8}$ & $\mathbf{5 4 5 , 3 9}$ & $\mathbf{3 7 7 , 5 3}$ & $\mathbf{4 3 0 , 2 1}$ \\
\hline
\end{tabular}

Sumber data : Otoritas Jasa Keuangan, 2020

Berdasarkan tabel diatas, bank umum syariah menjadi kontributor terbesar dalam mendukung keuangan syariah dibandingkan dengan unit usaha syariah dan bank pembiayaan rakyat syariah dalam membantu kenaikan kontribusi.

Penghimpunan dana atau modal yang dilakukan bank syariah tentunya menimbulkan biaya modal yang harus ditanggung oleh perusahaan sebagai kompensasi dalam rangka 
mendapatkan modal itu sendiri. Biaya modal adalah semua biaya yang secara riil dikeluarkan oleh perusahaan dalam rangka mendapatkan sumberdana. Sumberdana berasal dari pihak internal dan eksternal, yaitu yang berasal dari hutang, saham maupun laba ditahan untuk mendanai investasi dan operasional perusahaan (Ikit, 2018: 56).

Permaslahannya saat ini ialah biaya modal perbankan syariah yang mahal. Hal ini sesuai dengan kondisi saat ini dimana masih banyak bank syariah yang mengandalkan sumber dana atau modal yang berasal dari Dana Pihak Ketiga (DPK). Dana pihak ketiga perbankan berasal dari berbagai hal seperti tabungan, giro dan deposito. Dari instrumen sumber dana tersebut ada yang termasuk dana murah dan ada juga yang termasuk dana mahal. Dana murah perbankan adalah dana yang berasal dari tabungan dan giro, karena perbankan hanya memberikan rate atau tingkat pengembalian sebesar 2\%-5\%. Sebaliknya, sumber dana mahal perbankan adalah deposito, karena perbankan memang menawarkan tingkat rate atau pengembalian deposito yang lebih tinggi daripada tabungan dan giro, yaitu sebesar 5\%-7\% sebelum pajak.

Dengan masih bergantungnya modal atau sumber dana bank syariah yang berasal dari Dana Pihak Ketiga (DPK) yakni deposito. Maka biaya modal yang dikeluarkan bank syariah pun belum dapat ditekan seminimum atau seefisien mungkin atau dengan kata lain biaya modal yang dikeluarkan akan besar atau mahal. Hal ini menyebabkan laba yang diperoleh tidak maksimal. Karena biaya dari masing masing sumber berbeda beda, maka untuk menetapkan biaya modal perusahaan secara keseluruhan perlu menghitung biaya rata-rata tertimbang dari berbagai sumber dana tersebut. Konsep biaya modal dimaksudkan untuk dapat menentukan besarnya biaya riil dari penggunaan modal masing masing sumber dana untuk kemudian menetukan biaya rata-rata atau biaya modal rata rata tertimbang atau weighted average cost of capital (WACC). Rasio ini terbilang sangat komprehensif karena rasio ini merata-ratakan seluruh sumber modal. Dengan kata lain rasio ini mengukur bobot dan biaya sebenarnya dari utang dan pengumpulan dana ekuitas untuk mendanai pembelian aset dan ekspansi modal baru.

Selain dari biaya modal, profitabilitas yang dihasilkan juga dapat mempengaruhi nilai perusahaan. Profitabilitas merupakan kemampuan untuk menghasilkan/memperoleh laba secara efektif dan efisien (Anita Suwandani et al, 2017: 124). Profitabilitas perusahaan merupakan variabel penting yang dipertimbangkan perusahaan ketika akan berinvestasi. Tingkat profitabilitas yang tinggi menunjukkan perusahaan tersebut memiliki kinerja yang baik dan memiliki prospek di masa mendatang. Sehingga investor menangkap itu sebagai sinyal positif dan direspon dengan membeli saham perusahaan tersebut. Semakin banyak investor yang berminat membeli saham perusahaan berdampak pada meningkatnya harga saham perusahaan dan nilai perusahaan juga akan meningkat. Profitabilitas yang digunakan adalah ROE karena dapat memperhitungkan kemampuan manajemen perusahaan dalam mengelola aktiva yang dimilikinya untuk menghasilkan income. Semakin besar profitabilitas perusahaan, semakin besar pula tingkat keuntungan yang dicapai perusahaan tersebut dan semakin baik pula posisi perusahaan tersebut dari segi penggunaan modal.

Disamping itu banyak bank syariah yang belum bisa memaksimalkan instrumen sumberdananya berupa saham, dibuktikan dengan baru terdapat dua bank syariah yang melantai di Bursa Efek Indonesia (BEI) pada tahun 2019. Padahal potensi modal yang bisa didapat melalui pasar bursa sangatlah besar, terutama melalui sahamnya sebagai penyumbang sumber dana perusahaan guna pendanaan operasional bank syariah yang lebih aman dan murah karena semakin baik kinerja keuangan suatu perusahaan akan meningkatkan trust (kepercayaan) investor terhadap perusahaan tersebut. 


\section{STUDI LITERATUR}

Menurut (Muhammad, 2016: 500) mengenai Biaya Modal adalah semua biaya yang secara riil dikeluarkan oleh perusahaan untuk memperoleh sumber dana, biaya modal rata-rata merupakan suatu rasio untuk mengukur seluruh biaya yang dikeluarkan oleh perusahaan dalam memperoleh modal usaha. Profitabilitas merupakan kemampuan untuk menghasilkan atau memperoleh laba secara efektif dan efisien (Anita Suwandani et al, 2017: 124). Sedangkan Nilai Saham atau harga saham adalah harga yang terbentuk atas kekuatan permintaan dan penawaran di pasar bursa yang dipengaruhi oleh berbagai pertimbangan para investor baik faktor internal perusahaan itu sendiri maupun faktor eksternal (J.P. Sitanggang: 2014). Maka berdasarkan studi literatur tersebut penelitian ini bertujuan untuk mengetahui pengaruh biaya modal dengan metode WACC dan profitabilitas dengan rasio ROE terhadap nilai saham pada Bank BTPN Syariah. Pada penelitian ini menggunakan alat analisis statistik SPSS dimana hasil penelitiannya menunjukkan bahwa secara simultan biaya modal dan profitabilitas berpengaruh signifikan terhadap nilai saham. Dan secara parsial, biaya modal dengan metode Weighted Average Cost Of Capital (WACC) berpengaruh positif terhadap nilai saham, profitabilitas dengan rasio Return On Equity (ROE) berpengaruh negatif signifikan terhadap nilai saham. Dari penelitian ini diketahui bahwa biaya modal dan profitabilitas memiliki pengaruh yang signifikan terhadap nilai saham (Hary Sulistiyo, 2017; Carlo Alberto Magni, 2015).

Data yang digunakan pada penelitian ini yaitu berupa data Biaya modal, Profitabilitas dan Nilai saham Bank BTPN Syariah periode 2018-2020 yang diakses melalui website www.btpnsyariah.com. Metode analisis data dalam penelitian ini adalah regresi linear berganda. Hasil penelitian menemukan bahwa biaya modal berpengaruh positif sedangkan profitabilitas perpengaruh negatif (Krueger et al, 2011; A A Istri Rani Pradnyandari, Ida Bagus Putra Astika, 2019).

Variabel independen yang digunakan dalam penelitian ini adalah biaya modal (WACC) dan profitabilitas (ROE), sedangkan variabel dependen yang digunakan dalam penelitian ini adalah nilai saham Bank BTPN Syariah. Sampel dalam penelitian ini adalah laporan keuangan Bank BTPN Syariah perbulan periode 2018-2020 dan data historis harga saham Bank BTPN Syariah perbulan periode 2018-2020 (Haritz Faiz et al, 2019)

\section{Jenis dan Sumber Data}

\section{METODE}

Penelitian ini termasuk kedalam penelitian kuantitatif. Data kuantitatif adalah data berbentuk angka, misalnya harga saham, profitabilitas, aktiva, hutang (Anwar Sanusi, 2016). Keseluruhan data yang digunakan dalam penelitian ini adalah data sekunder berupa data time series. Dalam penelitian ini data yang digunakan berupa data Biaya modal, WACC, Profitabilitas, ROE dan Nilai saham Bank BTPN Syariah periode 20182020. Data diperoleh dari data yang dipublikasikan oleh Otoritas Jasa Keuangan dan Bank BTPN Syariah.

\section{Teknik Analisis Data}

\section{Statistik Deskriptif}

Statistik deskriptif merupakan proses transformasi data penelitian dalam bentuk tabulasi sehingga mudah dipahami dan diinterpretasikan.

\section{Uji Prasyarat}

Uji Normalitas 
Uji normalitas bertujuan untuk menguji apakah dalam model regresi, variabel residual memiliki distribusi normal atau tidak agar uji statistik untuk jumlah sampel kecil hasilnya tetap valid. Untuk menguji normalitas data dalam penelitian ini digunakan uji statistik Kolmogorov-Smirnov $(K-S)$.

\section{Uji Autokorelasi}

Autokorelasi (autocorrelation) adalah hubungan antara residual satu observasi dengan residual observasi lainnya. Autokorelasi lebih mudah timbul pada data yang bersifat runtun waktu, karena berdasarkan sifatnya, data masa sekarang dipengaruhi data pada masa-masa sebelumnya. Untuk mendeteksi ada atau tidaknya gejala autokorelasi dapat menggunakan uji Durbin- Watson $(D-W)$.

\section{Uji Hipotesis}

\section{Analisis Regresi Linier Berganda}

Analisis regresi linier berganda adalah suatu alat analisis peramalan nilai pengaruh dua variabel bebas atau lebih terhadap variabel terikat untuk membuktikan ada atau tidaknya hubungan fungsi atau hubungan kausal antara dua variabel bebas atau lebih dengan satu variabel terikat. Dengan demikian formulasi regresi linier berganda adalah sebagai berikut :

$$
\begin{aligned}
& \mathbf{Y}=\mathbf{b} \mathbf{0}+\mathbf{b} 1 \mathbf{X} 1+\mathbf{b} 2 \mathbf{X} 2+\mathbf{b 3 X 3}+\mathbf{e} \\
\text { Dimana }: \mathrm{Y} & =\text { Nilai Saham } \\
\mathrm{X} 1 & =\text { Biaya Modal }(\text { WACC }) \\
\mathrm{X} 2 & =\text { Profitabilitas }(\mathrm{ROE}) \\
\mathrm{b} 0 & =\text { Konstanta } \\
\mathrm{b} 1-\mathrm{b} 3 & =\text { Koefisien Regresi } \\
\mathrm{e} & =\text { Standar Error }
\end{aligned}
$$

\section{Koefisien Determinasi $\left(\mathbf{R}^{2}\right)$}

Koefisien determinasi yang sering disimbolkan dengan " $\mathbf{R}^{\mathbf{2}}$ " pada prinsipnya mengukur seberapa besar kemapuan model menjelaskan variasi variabel dependen.

\section{Uji Signifikan Secara Simultan (Uji f)}

Pengujian ini dilakukan untuk melihat pengaruh variabel independen terhadap variabel dependen secara serentak. Uji ini dilakukan untuk membandingkan pada tingkat nilai signifikansi dengan nilai $\alpha(5 \%)$ pada tingkat derajat $5 \%$.

\section{Uji Signifikan Secara Parsial (Uji t)}

Uji signifikansi ini dilakukan dengan menggunakan uji statistik t. pengujian ini dilakukan untuk melihat pengaruh variabel independen terhadap variabel dependen secara parsial dengan derajat keabsahan $5 \%$.

\section{Variabel Penelitian}

Variabel penelitian adalah suatu obyek atau kegiatan yang mempunyai variasi tertentu yang ditetapkan oleh peneliti untuk dipelajari dan ditarik kesimpulannya agar tidak terjadi penyimpangan dalam membahas dan menganalisis permasalahan penelitian yang dilakukan (Anwar Sanusi, 2016). Definisi operasional dilakukan agar tidak terjadi penyimpangan dalam membahas dan menganalisis permasalahan penelitian yang dilakukan. (Ridha, 2017)

Variabel terikat adalah variabel yang nilainya dipengaruhi oleh variabel lain. Variabel terikat penelitian ini adalah nilai saham (Y). Untuk variabel bebas terdiri dari 
variabel biaya modal dengan menggunakan metode WACC dan profitabilitas dengan menggunakan rasio ROE. Definisi operasional variabel dalam penelitian ini adalah sebagai berikut:

Biaya Modal (X1), Biaya modal adalah semua biaya yang secara riil dikeluarkan oleh perusahaan dalam rangka mendapatkan sumber dana. Maka bank perlu menghitung masing-masing biaya yang dikeluarkan oleh bank yaitu biaya hutang, biaya ekuitas dengan rumus biaya modal rata-rata tertimbang (WACC). Dengan rumus pengukuran sebagai berikut: [WACC $=$ WdKd $(1-T)+W e K e]$.

Profitabilitas (X2), Profitabilitas didefinisikan sebagai kemampuan perusahaan dalam memperoleh laba dalam hubungannya dengan penjualan, total aktiva maupun modal sendiri. Dengan rumus pengukuran: $(\mathrm{ROE})=\underline{\text { Laba Bersih Sebelum Pajak }}$

\section{Ekuitas}

Nilai Saham (Y), Nilai Saham atau harga saham adalah harga yang terbentuk atas kekuatan permintaan dan penawaran di pasar bursa yang dipengaruhi oleh berbagai pertimbangan para investor baik faktor internal perusahaan itu sendiri maupun faktor eksternal. Dengan rumus pengukuran sebagai berikut: Data harga historis saham Bank BTPN Syariah perbulan.

\section{HASIL}

Hasil penelitian meliputi beberapa ujian statistik, diantaranya sebagai berikut:

\section{Uji Prasyarat Analisis}

Tabel 1.2 Hasil Uji Normalitas Dengan Teknik One-Sample Kolmogorov-Smirnov Test

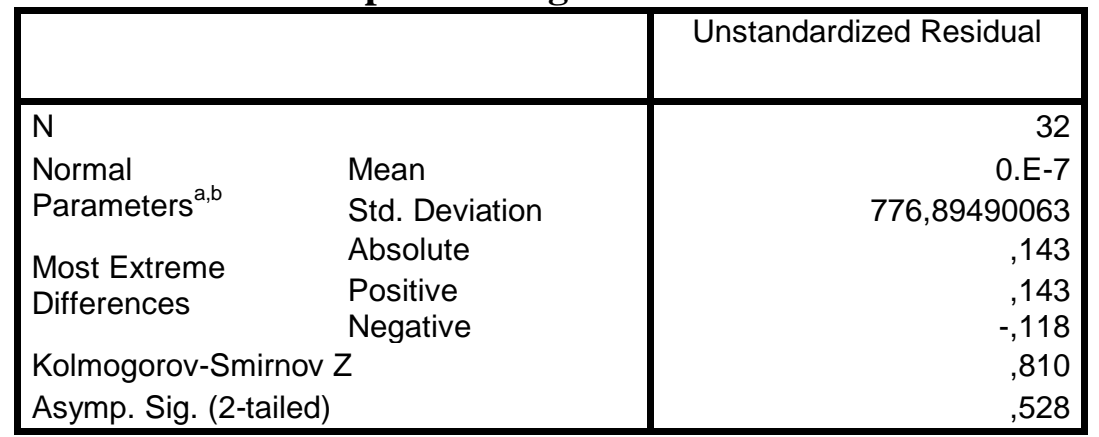

a. Test distribution is Normal.

b. Calculated from data.

Tabel 1.3 Hasil Uji Autokorelasi Model Summary ${ }^{\mathrm{D}}$

\begin{tabular}{|l|r|r|r|r|r|}
\hline Model & R & R Square & \multicolumn{1}{|c|}{$\begin{array}{c}\text { Adjusted R } \\
\text { Square }\end{array}$} & $\begin{array}{c}\text { Std. Error of the } \\
\text { Estimate }\end{array}$ & Durbin-Watson \\
\hline 1 &, $565^{\mathrm{a}}$ &, 319 &, 272 & 803,23776 & 1,446 \\
\hline
\end{tabular}

a. Predictors: (Constant), PROFITABILITAS, BIAYA MODAL

b. Dependent Variable: NILAI SAHAM

Dapat dilihat dari tabel 1.2 dari output tersebut dapat diketahui bahwa nilai signifikansi (asym.sig 2-tailed) sebesar 0,528. Karena signifikansi lebih dari 0,05 maka residual terdistribusi secara normal. Sedangkan pada tabel 1.3 mengenai hasil uji autokorelasi dapat dilihat pada tabel Model Summary diatas pada bagian kolom DurbinWatson yang menunjukan nilai Durbin Watson (dw) sebesar 1,446. Berdasarkan 
ketentuan uji ini, didapatkan nilai pada tabel Durbin-Watson dengan signifikasi $\alpha=5 \%$ dan $\mathrm{k}=2$, yaitu nilai dL sebesar 1,3093 dan nilai du sebesar 1,5770. Maka dapat disimpulkan bahwa nilai $\mathrm{dw}>\mathrm{dL}(1,446>1,3093)$ dan nilai $\mathrm{dw}<\mathrm{dU}(1,446<1,5770)$, dari hal tersebut maka dikatakan tidak terjadi autokorelasi. Maka hasil uji ini mengindikasikan bahwa penelitian ini tidak mengandung masalah autokorelasi.

\section{Tabel 1.4}

Ringkasan Hasil Uji Regresi Berganda dan Persamaan Regresi

\begin{tabular}{|c|c|r|r|r|l|}
\hline Variabel & Prediksi & $\begin{array}{c}\text { Koefisien } \\
\text { Regresi (b) }\end{array}$ & $\begin{array}{c}\text { T } \\
\text { hitung }\end{array}$ & Sig. & Kesimpulan \\
\hline (Konstanta) & & 2380,442 & 7,008 &, 000 & \\
\hline Biaya Modal (WACC) & Positif & 1006,490 & 3,681 &, 001 & Diterima \\
\hline Profitabilitas (ROE) & Negatif & $-439,791$ & $-3,656$ &, 001 & Diterima \\
\hline R Square & $=\mathbf{0 , 3 1 9}$ & \multicolumn{5}{|c|}{ Sig $=\mathbf{0 , 0 0 4}$} \\
\hline Adjusted R Square & $=\mathbf{0 , 2 7 2}$ &
\end{tabular}

Sumber : Data Primer Diolah, 2021

Berdasarkan tabel diatas dapat dijelaskan mengenai hubungan antar variabel bebas (biaya modal dan profitabilitas) dengan variabel terikat (nilai saham). Sehingga hasil data yang diperoleh pada tabel tersebut, maka dapat diperoleh persamaan sebagai berikut :

$\mathbf{Y}=\mathbf{a}+\mathbf{b} 1 \mathbf{X} 1+\mathbf{b} 2 \mathbf{X} 2$

Nilai Saham $=2380,442+1006,490+(-439,791)$

Keterangan :

a. Konstanta sebesar 2380,442, artinya jika Biaya Modal (X1) dan Profitabilitas (X2) nilainya adalah nol, maka nilai saham (Y) nilainya adalah 2380,442 .

b. Koefisien regresi variabel biaya modal (X1) sebesar 1006,490.

c. Koefisien regresi variabel profitabilitas (X2) sebesar - 439,791.

Nilai koefisien determinasi atau pengaruh biaya modal dan profitabilitas terhadap nilai saham ditunjukan oleh $\mathrm{R}^{2}$ ( $R$ Square) yaitu sebesar 0,319 atau $31,9 \%$. Dengan adanya nilai R Square sebesar 31,9\% berarti variabel independen mempengaruhi variabel dependen sebesar $31,9 \%$, sedangkan sisanya dipengaruhi oleh variabel lain yang tidak dimasukkan dalam penelitian ini.

Berdasarkan tabel 1.4 diatas, menjelaskan terkait hasil pengujian regresi dimana hal tersebut berguna untuk mengetahui ada tidaknya pengaruh, baik pengaruh secara parsial maupun secara simultan dengan melihat nilai $t_{\text {hitung, }} f_{\text {hitung }}$ dan dengan nilai signifikansinya sebesar 0,05 dengan tingkat kepercayaan sebesar 95\%. Sehingga hal ini dapat menjawab dan membuktikan hipotesis yang peneliti bangun dalam penelitian ini.

\section{PEMBAHASAN}

\section{Pengaruh Biaya Modal Terhadap Nilai Saham Bank BTPN Syariah}

Hasil penelitian yang telah dilakukan diatas dapat dikatakan bahwa biaya modal (WACC) berpengaruh positif dan signifikan terhadap nilai saham (NS). Dimana dilihat dari hasil pengujian secara parsial pengaruh biaya modal terhadap nilai saham, diperoleh nilai signifiaksi biaya modal (WACC) sebesar 0,001 < 0,05 (5\%), sehingga H0 ditolak dan Ha diterima. Selain itu koefisien WACC bernilai positif yaitu sebesar 1006,490 maka dapat disimpulkan bahwa arah pengaruh WACC terhadap nilai saham ialah positif. 
Sehingga dapat kita ketahui bahwa pengaruh WACC terhadap nilai saham Bank BTPN Syariah ialah berpengaruh positif dan signifikan.

Biaya modal harus dihitung dengan baik oleh perusahaan maupun bank sebagai landasan bagi keputusan investasi yang akan dilakukan oleh bank itu sendiri. Karena komponen modal yang digunakan harus ditentukan terlebih dahulu, akan berasal dari hutang ataupun modal sendiri. Seluruh komponen modal (capital components) mempunyai suatu kesamaan, yaitu investor yang menyediakan dana berharap untuk mendapatkan return yang baik dari investasi mereka. Struktur modal yang optimal dapat didefinisikan sebagai struktur modal yang memaksimalkan nilai perusahaan atau harga saham perusahaan, dan meminimumkan biaya modalnya.Biaya modal juga berfungsi sebagai middle rate ataupun cut off rate (tingkat pembatas) dalam evaluasi terhadap usulusul investasi yang akan dilakukan oleh bank. Apabila Rate Off Return (ROR) lebih besar daripada Cost Off Capital (Biaya Modal), maka usul investasi atau keputusan investasi bisa diterima.

Berdasarkan hasil analisa pada penelitian ini, biaya modal berpengaruh terhadap nilai saham, semakin baik pengelolaan biaya modal atau semakin minimum biaya modal yang dikeluarkan oleh bank syariah maka akan semakin meningkat pula nilai saham bank syariah tersebut. Karena jika biaya modal dapat diminimumkan, maka biaya modal bank tersebut bisa dikatakan murah atau pengeluaran bank untuk pengembalian modal bisa ditekan, sehingga laba yang diperoleh bank syariah akan meningkat, dengan meningkatnya laba yang diperoleh bank syariah maka investor akan mendapatkan imbal atau pengembalian investasi yang lebih besar dan baik, hal tersebut juga bisa mencerminkan nilai perusahan tersebut baik. Dengan membaiknya nilai perusahaan maka akan meningkatkantrust (kepercayaan) investor berinvestasi di perusahaan tersebut.

Perlu diperhatikan bahwa biaya modal pada bank syariah akan lebih menguntungkan dan berbeda bagiinvestor, karena pada bank syariah terdapat risk sharing, dan pada bank konvensional resiko ditanggung sepenuhnya oleh investor. Hal ini yang menjadikan bank syariah berbeda dengan bank konvensional sekaligus menjadi keunggulan dari bank syariah itu sendiri. Jadi jika investor atau perusahaan lain menanam modalnya atau meminjam modal pada bank syariah, risk sharing (berbagi resiko) tetaplah ada tidak ditanggung oleh peminjam atau investor saja.

Dengan demikian, bank harus mampu mengelola biaya modal yang ada dengan sangat baik, karena biaya modal sebagai pondasi bagi berjalannya operasional perbankan dan sebagai penyangga likuiditas sekaligus sebagai penentu seberapa besar laba atau keuntungan yang akan diterima oleh bank dari modal yang diinvestasikan, modal yang didapat dari investor maupun modal sendiri yang diperoleh oleh pemegang saham perusahaan. Terutama dalam hal mengelola modal sendiri, jika keputusan modal yang akan diinvestasikan bisa berasal dari modal bank sendiri maka bank dapat meminimalisir kegagalan keuangan. Hasil dari penelitian ini sejalan dengan penelitian yang dilakukan oleh Yoyon Supriyadi, Tarida M.S. Manurung, Fanny Atmaja Nataputra (2010), Hery Sulistiyo (2017) dan Harits Faiz Heriyantama, Muchamad Syafrudin (2019).

\section{Pengaruh Profitabilitas (ROE) Terhadap Nilai Saham}

Berdasarkan hasil penelitian yang telah dilakukan diatas dapat dikatakan bahwa profitabilitas (ROE) berpengaruh negatif dan signifikan terhadap nilai saham (NS). Dimana dilihat dari hasil pengujian secara parsial pengaruh profitabilitas terhadap nilai saham, diperoleh nilai signifiaksi profitabilitas (ROE) sebesar 0,001<0,05 (5\%), sehingga H0 ditolak dan Ha diterima. Selain itu koefisien ROE bernilai negatif yaitu sebesar -439,791 maka dapat disimpulkan bahwa arah pengaruh profitabilitas (ROE) 
terhadap nilai saham ialah negatif. Sehingga dapat kita ketahui bahwa pengaruh profitabilitas (ROE) terhadap nilai saham Bank BTPN Syariah ialah berpengaruh negatif dan signifikan.

(Kasmir, 2016: 117) mendefinisikan bahwa rasio profitabilitas merupakan rasio untuk menilai kemampuan perusahaan dalam mencari keuntungan. Rasio ini juga memberikan ukuran tingkat efektivitas manajemen suatu perusahaan. Hal ini dapat ditunjukkan oleh laba yang dihasilkan dari penjualan dan pendapatan investasi. Selaain itu Kasmir juga mendefinisikan Return On Equity (ROE) adalah rasio untuk mengukur laba bersih sesudah pajak dengan modal sendiri. Rasio ini menunjukkan efisiensi penggunaan modal sendiri. Semakin tinggi ROE, maka semakin baik. Artinya posisi perusahaan semakin kuat. Profitabilitas merupakan indikator yang paling penting untuk mengukur kinerja suatu perusahaan yang memfokuskan kemampuan perusahaan untuk memperoleh earning dalam kegiatan operasi perusahaan dengan memanfaatkan aktiva yang dimilikinya. Return On Equity (ROE) menggambarkan sejauhmana kemampuan perusahaan menghasilkan laba yang bias diperoleh pemegang saham.

Dengan demikian berdasarkan hasil dari penelitian ini menyatakan bahwa semakin besar profit yang diperoleh dari sebuah perusahaan tidak menjamin meningkatnya nilai dari saham. Bahkan dalam berinvestsi investor tidak melihat ROE sebagai salah satu alasan untuk membeli saham, sebab investor cenderung tidak menggunakan analisis fundamental dalam pengambilan keputusannya melainkan menggunakan kelompok referensi, pengalaman dan mengikuti pergerakan bandar (spekulasi) dalam berinvestasi, menunjukkan bahwa faktor psikologi dari investor mengambil peranan yang cukup penting dalam pengambilan keputusan investasi. Hasil dari penelitian ini sejalan dengan penelitian yang dilakukan oleh Tito albi Utama (2013), A.A. Istri Rani Pradnyandari, Ida Bagus Putra Astika (2019), Anita Suwandani suhendro, Anita Wijayanti (2017).

\section{Pengaruh Biaya Modal Dan Profitabilitas Terhadap Nilai Saham}

Berdasarkan hasil penelitian yang telah dilakukan, dapat disimpulkan bahwa terdapat pengaruh yang signifikan antara kedua variabel independen terhadap variabel dependen jika diuji secara bersamaan atau simultan. Kesimpulan ini didapat setelah mengetahui hasil uji simultan (uji F) yang menyatakan bahwa nilai Fhitung > Ftabel, yaitu sebesar $6,792>3,33$ dengan tingkat signifikan yang dihasilkan adalah $0,004<0,05$, sehingga $\mathrm{H} 3$ diterima dan $\mathrm{H} 0$ ditolak, yang mana hal tersebut menandakan bahwa biaya modal dan profitabilitas secara simultan berpengaruh signifikan terhadap nilai saham di Bank BTPN Syariah periode $2018-2020$.

WACC atau biaya modal rata-rata tertimbang adalah suatu rasio keuangan yang menghitung biaya pendanaan perusahaan untuk memperoleh aset dengan membandingkan struktur utang dan ekuitas bisnis. Profitabilitas merupakan kemampuan perusahaan dalam memperoleh laba dalam hubungannya dengan penjualan, total aktiva maupun modal sendiri. Sedangkan Nilai Saham atau harga saham adalah harga yang terbentuk atas kekuatan permintaan dan penawaran di pasar bursa yang dipengaruhi oleh berbagai pertimbangan para investor baik faktor internal perusahaan itu sendiri maupun faktor eksternal. Hasil dari penelitian ini mendukung penelitian yang telah dilakukan sebelumnya oleh Syarinah Sianipar (2017), Rita Kusumawati, Irham Rosady (2018) dan Bayu Irfandi Sanjaya, I.B. Panji Sedana (2015).

\section{KESIMPULAN}

Biaya modal Bank BTPN Syariah yang dihitung menggunakan metode Weighted Average Cost Off Capital (WACC) lebih dipengaruhi oleh biaya ekuitas, dan banyak 
keputusan modal yang dikeluarkan oleh Bank BTPN Syariah melalui sumber dana yang berasal dari ekuitas/modal bank itu sendiri. Biaya modal (WACC) berpengaruh positif dan signifikan terhadap nilai saham Bank BTPN Syariah. Secara keseluruhan sahamnya dimiliki oleh PT. Bank BTPN Syariah itu sendiri. biaya modal Bank BTPN Syariah memiliki nilai minimum sebesar $0,93 \%$ sedangkan nilai maksimum sebesar $12,12 \%$. Sedangkan Profitabilitas (ROE) berpengaruh negatif dan signifikan terhadap nilai saham Bank BTPN Syariah. Profitabilitas Bank BTPN Syariah yang dihitung menggunakan rasio ROE cukup baik setiap bulannya sebab nilai ROE secara keseluruhan di atas 8,32\% yang memperlihatkan nilai profitabilitas perusahaan baik. Dan Biaya Modal (WACC), Profitabilitas (ROE) secara simultan berpengaruh signifikan terhadap nilai saham Bank BTPN Syariah.

\section{REFERENSI}

A.A Istri Rani Pradyandari, I. B. (2019). Pengaruh Ukuran Perusahaan, Nilai Saham, Financial Leverage, Profitabilitas Pada Tindakan Perataan Laba di Sektor Manufaktur. Jurnal Akuntansi, 147-172.

al, N. L. (2019). Manajemen Keuangan Sebagai Dasar Pengambilan Keputusan Bisnis. Depok: PT. Raja Grafindo Persada.

Anita Suwandani, S. A. (2017). Pengaruh Profitabilitas Terhadap Harga Saham Peruahaan Manufaktur Sektor Makanan dan Minuman di Bali Tahun 2014-2015. Jurnal Akuntani , 124.

Bayu Irfandi Wijaya, I. P. (2015). Pengaruh Profitabilitas Terhadap ilai Perusahaan (Kebijakan Deviden dan Kesempatan Investasi Sebagai Variabe Meiasi). EJurnal Manajemen Unud, 4477-4500.

Brealey, M. M. (2011). Dasar-dasar Manajemen Keuangan Perusahaan . Jakarta: Erlangga.

Erwan Agus Purwanto, D. R. (2017). Metode Penelitian Kunatitatif Untuk Administrasi Pubik dan Masalah-masalah Sosial. Yogyakarta: Gava Media.

Eugene F. Brigham, J. F. (2014). Essentials of Financial Manajement (Dasar-dasar Manajemen Keuangan). Jakarta: Salemba Empat.

Ghozali, I. (2013). Aplikasi Analisis Multivariate Dengan Program IBM SPSS 21. Semarang: Universitas Diponogoro.

Haritz Faiz Heryantama, M. S. (2019). Analisis Pengaruh Tingkat Corporate Risk Disclosure (CRD) Terhadap Biaya Modal Ekuitas dan Kinerja Perusahaan (Sudi Empiris Terhadap Bank Yang Terdaftar di BEI Yang Telah di Audit PadaTahun 2015-2017). Jurnal Off Accounting , 65.

Ikit. (2018). Manajemen Dana Bank Syariah. Yogyakarta: Gava Media.

Intan Fitriyani, A. M. (2020). Analisis Biaya Modal Terhadap Tingkat Pengembalian Investasi Pada PT. Mitra Adiprakasa, Tbk. Jurnal Ekonomi Manajemen dan Bisnis , 65-70.

Karim, A. A. (2017). Ekonomi Makro Islam. Jakarta: PT. Raja Grafindo Persada.

Kasmir. (2016). Pengantar Manajemen Keuangan Edisi ke-2. Jakarta: Kencana .

Laporan Keuangan/anual report BTPN Syariah tersedia di http://www.btpnsyariah.com diakses pada tanggal (1 November 2021).

Laporan Perkembangan Keuangan Syariah Indonesia 2020 (On-Line), Tersedia di : http://www.ojk.go.id (1 November 2021).

Madani, D. (2015). Aspek Hukum Lembaga Keuangan Syariah di Indonesia. Jakarta: Kencana. 
Magni, C. A. (2015). Investment, Financing, anf The Role Of ROA and WACC in Value Creation. DEMB Working Paper Series, 28.

Muhammad. (2015). Manajemen Dana Bank Syariah. Jakarta: PT. Raja Grafindo Persada.

Muhammad. (2016). Manajemen Keuangan Syariah. Yogyakarta: UPP STIM YKPN.

Muhayatsyah, A. (2019). Biaya Modal dan Biaya Hutang Dalam Keuangan Islam. Jurnal J-Iscan .

N, R. (2017). Proses Penelitian, Masalah, Variabel dan Paradigma Penelitian. Jurnal Hikmah, 62-70.

Pavel, Z. (2018). The Impact Of Cash Flows and Weighted Average Cost Of Capital to Enterprise Value in The Oil and Gas Sector. Journal Of Review on Global Economics , 138-145.

Rita Kusumawati, I. R. (2018). Pengaruh Struktur Modal dan Profitabilitas Terhadap Nilai Perusahaan Dengan Kepemilikan Manajerial Sebagai Variabel Moderasi. Jurnal Manajemen Bisnis , 150.

Rizqi Aning Tyas, R. S. (2016). Analisis Pengaruh Proitabilitas Terhadap Harga Saham (Studi Kasus Perusahaan Telekomunikasi Yang Terdaftar di Bursa Efek Indonesia Periode 2012-2014). Jurnal Online Insan Akuntan , 77-91.

Sanusi, A. (2016). Metodologi Penelitian Bisnis. Jakarta: Salemba Empat.

Sianipar, S. (2017). Pengaruh Struktur Modal dan Profitabilitas Terhadap Nilai Perusahaan Pada Sektor Makanan dan Minuman yang Terdaftar di Bursa Efek Indonesia. Jom Fisip , 3.

Sitanggang, J. (2014). Faktor-faktor Yang Mempengaruhi Nilai Saham di Bursa Efek Indonesia. Jurnal Manajemen, 307-328.

Soemita, a. (2017). bank dan lembaga keuangan syariah. depok: kencana.

Sudana, I. M. (2015). Manajemen Keuangan Perusahaan. Surabaya: Erlangga.

Sugiono. (2016). Metode Peneitian Bisnis (Pendekatan Kuantitatif, Kualitatif dan R\&D). Bandung: Alfabeta.

Sujarweni, V. W. (2015). Metode Penelitian Bisnis \& Ekonomi. Yogyakarta: PT. Pustaka Baru.

Sulistiyo, H. (2017). Analisis Struktur Modal Terhadap WACC dan Analisis WACC Terhadap Nilai Saham. Jurnal Akuntansi , 262.

Suliyanto. (2011). Ekonomi Matrika Terapan Teori Aplikasi Dengan SPSS. Yogyakarta: Andi Offset.

Timotius, K. H. (2017). Pengantar Metode Penelitian. Yogyakarta: Andi Offset.

Tito Albi Utama, A. R. (2013). Pengaruh Corporate Governance Perception Index, Profitabilitas, Leverage dan Ukuran Perusahaan Terhadap Nilai Saham. Jurnal Off Accounting , 56-64.

Yoyon Supriyadi, T. M. (2010). Pengaruh WACC Terhadap Nilai Perusahaan . Jurnal Ilmiah Ranggagading , 32-44. 